\title{
Assessing Special Needs of Students with Hearing Impairment in Jordan and Its Relation to Some Variables
}

\author{
Ibrahim A. El-Zraigat ${ }^{1}$ \\ ${ }^{1}$ Faculty of Educational Sciences, Department of Counseling and Special Education, University of Jordan, \\ Jordan \\ Correspondence: Ibrahim A. El-Zraigat, Associate Professor, Faculty of Educational Sciences, Department of \\ Counseling and Special Education, The University of Jordan, P. O. Box 13144, Amman 11942, Jordan. Tel: \\ 962-777-423-526. E-mail: ibrahimz@ju.edu.jo/ibrahim_zraigat@hotmail.com
}

Received: November 7, 2012 Accepted: December 3, 2012 Online Published: December 18, 2012

http://dx.doi.org/10.5539/ies.v6n2p63

URL: http://dx.doi.org/10.5539/ies.v6n2p63

This study is funded by The University of Jordan

\begin{abstract}
The main purpose of the present study was to assess special needs for students with hearing impairment. The sample of the study consisted of 231 students enrolled at schools for deaf children in Jordan, 113 males and 118 females. A special needs scale was developed and used in assessing special needs for students. The reliability and validity of the scale were established. The investigator used the t-test and ANOVA to answer the research questions. The results indicated that the differences between all pairs of means for both male and female respondents were statistically non-significant. Also, findings showed that the hearing-impaired students who have 55-69 dB hearing loss were more affected by communication needs, audiological rehabilitation needs, and learning style needs than hearing-impaired students who have $90 \mathrm{~dB}$ hearing loss and beyond hearing loss. In addition to, findings revealed that the grade groups of 2-5 and 6-8 were more affected than grade group of 9-11 for the following dependent variables: communication needs, social and emotional needs, personal needs, behavioral needs, and academic needs. Also, the grade group of 6-8 was more affected than the grade groups of 2-5 and 9-11 with respect to the dependent variable of learning style needs. Differences between mean scores of students who used sign language and total communication were in favor of students who used total communication on the dimensions of communication needs, audiological rehabilitation needs, behavioral needs, and learning style needs. The study recommended on meeting the needs of students with hearing impairment throughout planned programs .
\end{abstract}

Keywords: deaf, hard-of-hearing, special needs, hearing impairment, special education, Jordan

\section{Introduction}

The various definition of hearing impairment indicates that it's a generic term covering all degrees and types of hearing loss, and refers to the reduced function in hearing and understanding speech and language that result from auditory disorder (Dahl, 1994; Stach, 2010). Hearing-impaired student is a term that includes both the deaf and hard-of-hearing student (Moores, 2001). Northern and Downs (2002) maintains that deaf student as the one whose hearing is impaired to the extent of $70 \mathrm{~dB}$ and above, while hard-of-hearing student is viewed as the one whose hearing is disabled to the extent of 16-69 dB. Educationally, a deaf student is unable to understand speech and process linguistic information through audition, with or without hearing aids. A hard-of-hearing is the one who has residual hearing and with the use of hearing aids can understand speech and process linguistic information (Hallahan, Kauffman, \& Pullen, 2012).

Students with hearing impairment are considered as learners with special needs. Hearing impairment affects the developmental milestones especially language and communication development. However, speech and language abilities of students with hearing impairment negatively influenced according to the degree and type of hearing loss (Gillam \& Gillam, 2011; English, 1995). Therefore, hearing impairment challenges the abilities to learn and participate at schools and in society, as well as students who are deaf and hard-of-hearing can be handicapped by the educational system and attitudes of the society (Paul, 2009; Paul \& Whitelaw, 2011). 
The impact of hearing impairment occurs throughout communication and social interaction with others, and carrying out daily life activities. In the school community, many students who are deaf and hard-of-hearing avoid contact with their hearing peers; they do not feel free to participate in school activities (Scheetz, 2004; Smith, 2007). The lack of opportunities for communicating and interacting with others are among other factors that precludes the acquisition of social experiences, and limits the development of positive self-esteem (Heward, 2006). Further, Reich and Lavay (2009) indicate that some teachers can be confused throughout communicating with deaf or hard-of-hearing students in the school community, because they are most often grouped together.

Beveridge (1997) stresses those students who are deaf and hard-of-hearing require speech and language services in addition to audiology and special education services. Bunch (1987) and Schrimer (2001) maintain the importance of designing special curricula for addressing the special needs of students who are deaf and hard-of-hearing. They indicate that the needs of this group of students may include special speech and language instruction, audiological rehabilitation, and instruction through visual and manual methods.

\section{Literature Review}

Researchers have demonstrated the variety of needs of students who are deaf and hard-of-hearing. For example, Dimiling (2010) indicates that deaf and hard-of-hearing students may need special vocabulary intervention in order to improve their recognition, production, and comprehension of the words and phrases. Wolters, Knoors, Cillessen, and Verhoeven (2011) show that deaf students have severe language problems compared to their hearing classmates. To address increasing needs of students who are deaf and hard-of-hearing for speech and language services, Houston and Perigoe (2010) report that this group of students need access to skilled professionals who can improve receptive and expressive language throughout planned programs. Gilbertson and Ferre (2008) present major difficulties when making educational decisions regarding students who are deaf and hard-of-hearing. Among of these challenges are reading difficulties, language acquisition skills, and school learning activities. Esera (2008) and Schick, Williams, and Kupermintz (2006) highlight the educational needs of deaf and hard-of-hearing students. They maintain that among educational needs of this group of students are learning environment, educational interpreters, communication, using visual approach, and applying evidence based practices in instruction. Also, Anderson-Inman and Terrazas-Arellannes (2009) successfully linked unfamiliar words to vocabulary, labelled illustrations, or concept maps. Furthermore, Sinnott (2009) emphases the significance of creating positive environment and supporting suitable behaviours for hearing-impaired students.

Reviewing literature regarding the counselling needs of students who are deaf and hard-of-hearing suggests that this group of students need special designed counselling programs to educate them deaf identity development and deaf culture (Whyte \& Guiffrida, 2008). Further, Wolters et al. (2011) indicate that deaf students who have some problems with their social behaviour that affect negatively their social acceptance. They also find that deaf girls show lower level of antisocial behaviour than deaf boys. Reviewing related literature of the special needs of students who are deaf and hard-of-hearing indicates that these needs differ according to educational environment, curriculum, grade level, and severity of hearing loss of the student (Donne \& Zigmond, 2008). In many cases, Johnson and Seaton (2012) indicate that students who are deaf and hard-of-hearing do not access to a sufficient schooling, and they are not receiving a full range of services that address their unique needs. Thus, students who are deaf and hard-of-hearing require special services in order to meet their needs and to help them achieve their maximum potential.

\section{Statement the Problem and Importance of the Study}

Jordan is a small country located in the Middle East with limited resources and depends on the development of the human resources. As many other countries, Jordanian Government paid special interest to persons with disabilities especially after the declaration of United Nations in 1981 a year specified for the disabled person. Regarding to, Jordan issued the law for the welfare of disabled person in 1993 and modified it in 2007. The Ministry of Education established 10 schools for students who are deaf and hard-of-hearing located in most populated cities. The Ministry of Education represented by The Directorate of Special Education assumed full responsibility of educating students who are deaf and hard-of-hearing, and supplies these schools with the support needed in order to achieve the maximum potential of these students (Ministry of Education, 2010). Educating students who are deaf and hard-of-hearing in Jordan are challenging with many difficulties, such as, lack of remedial and educational programs, insufficient teachers, unequipped schools, and lack of instructional and assessment. Furthermore, these groups of students study the same curricula designed for hearing students and they have the same educational cycle (El-Zraigat \& Smadi, 2012). However, Moores (2001) indicates that there are differences between hearing-impaired students and hearing students in how they are taught, in what they are taught, and in where they should taught. Therefore, addressing the special needs of students who are deaf and 
hard-of-hearing must be based on assessing these needs. The information gathered by assessment plays a crucial role for determining the educational goals and providing services with modifications as needed in order to meet the needs of students who are deaf and hard-of-hearing. Therefore, the stated aim of this study is to assess the special needs of students who are deaf and hard-of-hearing in Jordan.

\subsection{Importance of the Study}

The investigator reviewed the data basis available in the universities of Jordan, such as, published articles and proceeding conferences focusing on educating students who are deaf and hard-of-hearing, documents available at The Ministry of Education in Jordan related to deaf education. The process of reviewing clearly indicated that there is no study targeted the assessment of special needs of students who are deaf and hard-of-hearing in Jordan. Therefore, the overall purpose of the study is to assess the special needs of students who are deaf and hard-of-hearing in Jordan. Assessing these needs is crucial in determining the best ways of identifying and meeting the unique needs of this group of students. The results of the study will be considered as a basis for determining the educational goals for students who are deaf and hard-of-hearing, and designing appropriate services, modifications and programs to the students as required. In addition to, the findings of present study will help to suggest recommendations especially for The Ministry of Education, The Higher Council for Persons with Disabilities, and other authorities in Jordan who care about students who are deaf and hard-of-hearing. Furthermore, the present study aims to provide them with new information that they may take into consideration when they deliver the special educational services to students who are deaf and hard-of-hearing. Finally, the results of the study may contribute to get better understanding of the special needs of the targeted groups by teachers, parents, and all concerned authorities in Jordan.

\section{Questions of the Study}

The following research questions were addressed:

- What are the special needs of students who are deaf and hard-of-hearing in Jordan?

- Do the special needs of students who are deaf and hard-of-hearing in Jordan significantly differ compared to their gender?

- Do the special needs of students who are deaf and hard-of-hearing in Jordan significantly differ compared to their level of hearing loss?

- Do the special needs of students who are deaf and hard-of-hearing in Jordan significantly differ compared to their grade?

- Do the special needs of students who are deaf and hard-of-hearing in Jordan significantly differ compared to their communication methods?

\section{Research Methodology}

\subsection{Population of the Study}

Four schools of students who are deaf and hard-of-hearing were selected based on the number of students who are registered. One of these schools is a residential school and the others are day schools. However, the selected schools located on the most population regions. Around $70 \%$ from the whole population of Jordan live in these regions.

The total of the sample reached 231 subjects, 113 males and 118 females distributed among these schools. The selected residential and day schools followed and supervised by The Ministry of Education. The residential school (The Holy Land Institute for deaf children) delivers accommodation service for students who are deaf and hard-of-hearing who come from other regions, uses sign language in the teaching process, and includes a vocational division which aims at teaching students different careers and providing them with appropriate training. The three remaining schools use sign language and lip-reading in teaching the students who are deaf and hard-of-hearing.

\subsection{Constructing the Study Instrument}

To study the special needs of students who are deaf and hard-of-hearing in Jordan, a Special Needs of Students who are Deaf and Hard-of-Hearing Scale (SNSDHHS) has been developed. The (SNSDHHS) was developed through four steps: the first step of preparing the (SNSDHHS) was the pilot study which focuses on obtaining information about students who are deaf and hard-of-hearing in Jordan. The second step consisted of reviewing the related literature of special needs of students who are deaf and hard of hearing. In the third step, the investigator prepared the (SNSDHHS). The last step, distributing the (SNSDHHS) of assessing the needs of 
students who are deaf and hard-of-hearing among the experts (judges) in order to achieve the content validity. The content validity was based on asking 10 experts to evaluate the (SNSDHHS) with specific directions to make their judgments depending on two major questions: are the dimensions related to special needs of students who are deaf and hard-of-hearing? Are the items of the dimensions related to section they put in? The items were accepted by the experts and were used in the present study. This process produced a Special Needs of Students who are Deaf and Hard-of-Hearing Scale (SNSDHHS) in Jordan. The (SNSDHHS) is consisting of 70 sub-items divided within seven core dimensions as the following:

Table 1. Core dimensions and number of sub-items of the (SNSDHHS) in Jordan

\begin{tabular}{ll}
\hline Core dimensions & Number of sub-items \\
\hline Communication needs & 13 \\
Audiological rehabilitation needs & 7 \\
Social and emotional needs & 9 \\
Personal needs & 8 \\
Behavioral needs & 9 \\
Academic needs & 16 \\
Learning style needs & 8 \\
\hline
\end{tabular}

The reliability of (SNSDHHS) has been achieved by coefficients Alpha and test-retest reliability in which the investigator has administered (SNSDHHS) to one group, after two weeks, the same group were given again (SNSDHHS), and correlated the two sets of scores. The coefficients Alpha and test-retest reliability for (SNSDHHS) in Jordan is given in Table 2.

Table 2. The coefficients of reliability (test-retest and Alpha) for (SNSDHHS) in Jordan

\begin{tabular}{llll}
\hline Core dimensions & $\begin{array}{l}\text { Number of } \\
\text { sub-items }\end{array}$ & $\begin{array}{l}\text { test-retest } \\
\text { reliability }\end{array}$ & $\begin{array}{l}\text { Coefficient } \\
\text { Alpha }\end{array}$ \\
\hline Communication needs & 13 & .87 & 0.96 \\
Audiological rehabilitation needs & 7 & .84 & 0.90 \\
Social and emotional needs & 9 & .81 & 0.96 \\
Personal needs & 8 & .79 & 0.92 \\
Behavioral needs & 9 & .80 & 0.96 \\
Academic needs & 16 & .89 & 0.97 \\
Learning style needs & 8 & .83 & 0.94 \\
\hline
\end{tabular}

It is observed from data in Table. 2 that all coefficients of test-retest reliability for the dimensions are over .79. Also, the findings revealed that coefficients Alpha are over 90. However, these coefficients reflect the stability and indicate that the (SNSDHHS) has good reliability and it is accepted for the purpose of the study.

The items of (SNSDHHS) were included of four-grade Likert Scale items ranging from strongly disagree to strongly agree to reflect the level of the needs were assigned with statements as follows: $1=$ strongly disagree, $2=$ disagree, $3=$ agree, and $4=$ strongly agree.

\subsection{Design of the Study}

The present study is a survey research in which the data is organised in form of numbers and analysed by using a statistical analysis programs. The Data gathered throughout Special Needs of Students who are Deaf and Hard-of-Hearing Scale (SNSDHHS) developed by the investigator for obtaining the goal of the study. The study was included the following variables: level of hearing loss (35-54 dB, 55-69 dB, 70-89dB, $90 \mathrm{~dB}$ and beyond), gender (male, female), grade, and communication method (sign language, total communication).

\subsection{Procedures of the Study}

During the data collection process, the investigator sent a package of information to the principals of each identified schools. A covering letter and copies of (SNSDHHS) were included in each package. After the principal agreed on his/her participation in the study, the investigator held a meeting with the principals and teachers to explain the purpose of the study and the way of filling (SNSDHHS). Then principals distributed (SNSDHHS) among the teachers. These teachers were helped their students who are deaf and hard-of-hearing to 
fill the scale by estimating their unique needs and puting the sign of $(\times)$ in the appropraite place of four-grade Likert Scale. Finally, gathering all information about students including the degree of their hearing loss from their files in their schools in co-operation with their teachers.

After completing data collection, the data was analysed according to SPSS programme. Descriptive statistics, independent sample test, one-way analysis of covariance (ANOVA), and post hoc test (TUKEY) were used in analysing the data.

\section{Results of the Study}

The presentation of the results is structured around specific questions related to the general aim.

6.1 What are the Special Needs of Students Who are Deaf and Hard-of-Hearing in Jordan?

This question has been answered by calculating the means and standard deviation of the participans as showed in the following table.

Table 3. The means and standard deviations of the dimensions of the (SNSDHHS)

\begin{tabular}{lll}
\hline Core diminsions & Means & Standard deviation \\
\hline Communication needs & 2.84 & 0.686 \\
Audiological rehabilitation needs & 2.79 & 0.614 \\
Social and emotional needs & 3.08 & 0.579 \\
Personal needs & 3.14 & 0.532 \\
Behavioral needs & 3.03 & 0.550 \\
Academic needs & 2.94 & 0.630 \\
Learning style needs & 3.00 & 0.599 \\
\hline
\end{tabular}

The data in the table indicates that hearing-impaired students are affected by the dependent variables according to the means

\subsection{Do the Special Needs of Student Who are Deaf and Hard-of-Hearing in Jordan Significantly Differ Compared to Their Gender?}

This question has been answered by using independent samples t-test. The summary of independent samples t-test of the special needs comparing gender is shown in Table 4.

Table 4. The means and results of independent samples t-test of the dependent variables comparing gender

\begin{tabular}{|c|c|c|c|c|c|}
\hline Core dimensions & Gender & Means & $\begin{array}{l}\text { Standard } \\
\text { deviation }\end{array}$ & $\mathbf{t}$ & Sig. \\
\hline \multirow[t]{2}{*}{ Communication needs } & Male $(\mathrm{N}=113)$ & 2.84 & 0.657 & 0.104 & 0.918 \\
\hline & Female $(\mathrm{N}=118)$ & 2.83 & 0.715 & & \\
\hline \multirow[t]{2}{*}{ Audiological rehabilitation needs } & Male $(\mathrm{N}=113)$ & 2.78 & 0.615 & 0.111 & 0.911 \\
\hline & Female $(\mathrm{N}=118)$ & 2.77 & 0.613 & & \\
\hline \multirow[t]{2}{*}{ Social and emotional needs } & Male $(\mathrm{N}=113)$ & 3.11 & 0.577 & 0.960 & 0.338 \\
\hline & Female $(\mathrm{N}=118)$ & 3.04 & 0.604 & & \\
\hline \multirow[t]{2}{*}{ Personal needs } & Male $(\mathrm{N}=113)$ & 3.19 & 0.511 & 1.459 & 0.146 \\
\hline & Female $(\mathrm{N}=118)$ & 3.09 & 0.552 & & \\
\hline \multirow[t]{2}{*}{ Behavioral needs } & Male $(\mathrm{N}=113)$ & 3.05 & 0.541 & 0.414 & 0.679 \\
\hline & Female $(\mathrm{N}=118)$ & 3.02 & 0.565 & & \\
\hline \multirow[t]{2}{*}{ Academic needs } & Male $(\mathrm{N}=113)$ & 2.95 & 0.657 & 0.403 & 0.687 \\
\hline & Female $(\mathrm{N}=118)$ & 2.92 & 0.600 & & \\
\hline \multirow[t]{2}{*}{ Learning style needs } & Male $(\mathrm{N}=113)$ & 3.05 & 0.561 & 1.456 & 0.147 \\
\hline & Female $(\mathrm{N}=118)$ & 2.95 & 0.557 & & \\
\hline
\end{tabular}


The data in the table indicates that both male and female hearing-impaired students are not affected by the dependent variables according to the means; it indicates that the differences between all pairs of means for both male and female respondents are statistically non-significant.

6.3 Do the Special Needs of Students Who are Deaf And Hard-of-Hearing in Jordan Significantly Differ Compared to Their Level of Hearing Loss?

This question has been answered by using one-way analysis of variance. Table 5 . shows the means and results of one-way analysis of variance of the special needs comparing degree of hearing loss of hearing-impaired students.

Table 5. The means and results of one-way analysis of variance of the dependent variables comparing the degree of hearing loss of hearing-impaired students

\begin{tabular}{|c|c|c|c|c|c|}
\hline Core dimensions & Level of hearing loss & Means & $\begin{array}{l}\text { Standard } \\
\text { deviation }\end{array}$ & $\mathbf{F}$ & Sig. \\
\hline \multirow[t]{4}{*}{ Communication needs } & $35-54 \mathrm{~dB}(\mathrm{~N}=16)$ & 2.94 & 0.573 & 5.263 & 0.002 \\
\hline & $55-69 \mathrm{~dB}(\mathrm{~N}=21)$ & 3.25 & 0.423 & & \\
\hline & $70-89 \mathrm{~dB}(\mathrm{~N}=60)$ & 2,96 & 0.481 & & \\
\hline & $90 \mathrm{~dB}$ and beyond $(\mathrm{N}=136)$ & 2.71 & 0.769 & & \\
\hline \multirow[t]{4}{*}{ Audiological rehabilitation needs } & $35-54 \mathrm{~dB}(\mathrm{~N}=16)$ & 2,86 & 0.449 & 11.417 & 0.000 \\
\hline & $55-69 \mathrm{~dB}(\mathrm{~N}=21)$ & 3.22 & 0.499 & & \\
\hline & $70-89 \mathrm{~dB}(\mathrm{~N}=60)$ & 3.01 & 0.500 & & \\
\hline & $90 \mathrm{~dB}$ and beyond $(\mathrm{N}=136)$ & 2.61 & 0.634 & & \\
\hline \multirow[t]{4}{*}{ Social and emotional needs } & $35-54 \mathrm{~dB}(\mathrm{~N}=16)$ & 3.05 & 0,391 & 0.917 & 0.433 \\
\hline & $55-69 \mathrm{~dB}(\mathrm{~N}=21)$ & 3.21 & 0.423 & & \\
\hline & $70-89 \mathrm{~dB}(\mathrm{~N}=60)$ & 3.14 & 0.423 & & \\
\hline & $90 \mathrm{~dB}$ and beyond $(\mathrm{N}=136)$ & 3.03 & 0.670 & & \\
\hline \multirow[t]{4}{*}{ Personal needs } & $35-54 \mathrm{~dB}(\mathrm{~N}=16)$ & 3.05 & 0.465 & 0.649 & 0,585 \\
\hline & $55-69 \mathrm{~dB}(\mathrm{~N}=21)$ & 3.28 & 0.362 & & \\
\hline & $70-89 \mathrm{~dB}(\mathrm{~N}=60)$ & 3.14 & 0.378 & & \\
\hline & $90 \mathrm{~dB}$ and beyond $(\mathrm{N}=136)$ & 3.13 & 0.614 & & \\
\hline \multirow[t]{4}{*}{ Behavioural needs } & $35-54 \mathrm{~dB}(\mathrm{~N}=16)$ & 2.94 & 0.349 & 2.269 & 0.081 \\
\hline & $55-69 \mathrm{~dB}(\mathrm{~N}=21)$ & 3.29 & 0.437 & & \\
\hline & $70-89 \mathrm{~dB}(\mathrm{~N}=60)$ & 3.09 & 0.464 & & \\
\hline & $90 \mathrm{~dB}$ and beyond $(\mathrm{N}=136)$ & 2.98 & 0.608 & & \\
\hline \multirow[t]{4}{*}{ Academic needs } & $35-54 \mathrm{~dB}(\mathrm{~N}=16)$ & 2.94 & 0.439 & 2.089 & 0.102 \\
\hline & $55-69 \mathrm{~dB}(\mathrm{~N}=21)$ & 3.19 & 0.433 & & \\
\hline & $70-89 \mathrm{~dB}(\mathrm{~N}=60)$ & 3.02 & 0.509 & & \\
\hline & $90 \mathrm{~dB}$ and beyond $(\mathrm{N}=136)$ & 2.87 & 0.708 & & \\
\hline \multirow[t]{4}{*}{ Learning style needs } & $35-54 \mathrm{~dB}(\mathrm{~N}=16)$ & 2.99 & 0.314 & 3.783 & 0.011 \\
\hline & $55-69 \mathrm{~dB}(\mathrm{~N}=21)$ & 3.27 & 0.488 & & \\
\hline & $70-89 \mathrm{~dB}(\mathrm{~N}=60)$ & 3.11 & 0.358 & & \\
\hline & $90 \mathrm{~dB}$ and beyond $(\mathrm{N}=136)$ & 2.91 & 0.644 & & \\
\hline
\end{tabular}

As reported in the table, the dependent variables affect the special needs of hearing-impaired students with their different hearing loss according to their means. The differences between the means of the degree of hearing loss with respect to communication needs, audiological rehabilitation needs, and learning style needs are statistically 
significant. Inspection of the p-values compared to TUKEY test show that the hearing-impaired students who have 55-69 dB hearing loss are more affected by communication needs, audiological rehabilitation needs, and learning style needs than hearing-impaired students who have $90 \mathrm{~dB}$ and beyond hearing loss.

6.4 Do the Special Needs of Students Who are Deaf and Hard-of-Hearing in Jordan Significantly Differ Compared to Their Grade?

This question has been answered by using one-way analysis of variance. Table 6 . shows the means and the results of one-way analysis of variance of the special needs comparing grade of hearing-impaired students.

Table 6. The means and results of one-way analysis of variance of the dependent variables comparing the grade of hearing-impaired students

\begin{tabular}{|c|c|c|c|c|c|}
\hline Core dimensions & $\begin{array}{l}\text { Grade } \\
\text { hearing-impaired } \\
\text { students }\end{array}$ & Means & $\begin{array}{l}\text { Standard } \\
\text { deviation }\end{array}$ & $\mathbf{F}$ & Sig. \\
\hline \multirow[t]{3}{*}{ Communication needs } & Grade $2-5(\mathrm{~N}=74)$ & 2.96 & 0.613 & 8.813 & 0.000 \\
\hline & Grade $6-8(\mathrm{~N}=77)$ & 2.99 & 0.664 & & \\
\hline & Grade $9-11(\mathrm{~N}=82)$ & 2.59 & 0.706 & & \\
\hline \multirow[t]{3}{*}{ Audiological rehabilitation needs } & Grade $2-5(\mathrm{~N}=74)$ & 2.79 & 0.568 & 0.040 & 0.960 \\
\hline & Grade $6-8(\mathrm{~N}=77)$ & 2.80 & 0.578 & & \\
\hline & Grade $9-11(\mathrm{~N}=82)$ & 2.77 & 0.689 & & \\
\hline \multirow[t]{3}{*}{ Social and emotional needs } & Grade $2-5(N=74)$ & 3.11 & 0.432 & 15.664 & 0.000 \\
\hline & Grade 6-8 $(\mathrm{N}=77)$ & 3.31 & 0.593 & & \\
\hline & Grade $9-11(\mathrm{~N}=82)$ & 2.82 & 0.590 & & \\
\hline \multirow[t]{3}{*}{ Personal needs } & Grade $2-5(N=74)$ & 3.28 & 0.426 & 14.947 & 0.000 \\
\hline & Grade 6-8 $(\mathrm{N}=77)$ & 3.26 & 0.464 & & \\
\hline & Grade $9-11(\mathrm{~N}=82)$ & 2.89 & 0.594 & & \\
\hline \multirow[t]{3}{*}{ Behavioural needs } & Grade $2-5(\mathrm{~N}=74)$ & 3.19 & 0.479 & 11.309 & 0.000 \\
\hline & Grade 6-8 $(\mathrm{N}=77)$ & 3.12 & 0.460 & & \\
\hline & Grade $9-11(\mathrm{~N}=82)$ & 2.81 & 0.621 & & \\
\hline \multirow[t]{3}{*}{ Academic needs } & Grade $2-5(N=74)$ & 2.98 & 0.463 & 10.689 & 0.000 \\
\hline & Grade 6-8 $(\mathrm{N}=77)$ & 3.15 & 0.645 & & \\
\hline & Grade $9-11(\mathrm{~N}=82)$ & 2.71 & 0.675 & & \\
\hline \multirow[t]{3}{*}{ Learning style needs } & Grade $2-5(\mathrm{~N}=74)$ & 2.97 & 0.420 & 11.164 & 0.000 \\
\hline & Grade 6-8 $(\mathrm{N}=77)$ & 3.21 & 0.549 & & \\
\hline & Grade $9-11(\mathrm{~N}=82)$ & 2.82 & 0.611 & & \\
\hline
\end{tabular}

The findings in the table report that all grade groups of hearing-impaired students are affected by the dependent variables according to the means. Also, the data shows that the differences between the means of grade groups are statistically significant for all dependent variables except the dimension of audiological rehabilitation needs. Multiple comparison using TUKEY test indicate that the grade groups of 2-5 and 6-8 are more affected by the following dependent variables than grade group of 9-11: communication needs, social and emotional needs, personal needs, behavioural needs, and academic needs. Also, the grade group of 6-8 is more affected than the grade groups of 2-5 and 9-11 with respect to dependent variable of learning style needs.

6.5 Do the Special Needs of Students Who are Deaf and Hard-of-hearing in Jordan Significantly Differ Compared to Their Communication Methods?

This question has been answered by using independent samples t-test. Table 7. shows the means and standard deviation, and summary of independent samples t-test of the special needs comparing communication methods 
of hearing-impaired students. The summary of independent samples t-test of the special needs comparing communication methods is shown in Table 7.

Table 7. The means and results of independent samples t-test of the dependent variables comparing communication methods

\begin{tabular}{|c|c|c|c|c|c|}
\hline Core dimensions & communication methods & Means & $\begin{array}{l}\text { Standard } \\
\text { deviation }\end{array}$ & $\mathbf{t}$ & Sig. \\
\hline \multirow[t]{2}{*}{ Communication needs } & Sign language $(\mathrm{N}=165)$ & 2.78 & 0.701 & 1.917 & 0.047 \\
\hline & $\begin{array}{l}\text { Total communication } \\
(\mathrm{N}=65)\end{array}$ & 2.97 & 0.631 & & \\
\hline \multirow[t]{2}{*}{ Audiological rehabilitation needs } & Sign language $(\mathrm{N}=165)$ & 2.67 & 0.558 & 4.738 & 0.000 \\
\hline & $\begin{array}{l}\text { Total communication } \\
(\mathrm{N}=65)\end{array}$ & 3.07 & 0.654 & & \\
\hline \multirow[t]{2}{*}{ Social and emotional needs } & Sign language $(\mathrm{N}=165)$ & 3.05 & 0.627 & 1.273 & 0.144 \\
\hline & $\begin{array}{l}\text { Total communication } \\
(\mathrm{N}=65)\end{array}$ & 3.15 & 0.440 & & \\
\hline \multirow[t]{2}{*}{ Personal needs } & Sign language $(\mathrm{N}=165)$ & 3.10 & 0.576 & 1.645 & 0.058 \\
\hline & $\begin{array}{l}\text { Total communication } \\
(\mathrm{N}=65)\end{array}$ & 3.23 & 0.398 & & \\
\hline \multirow[t]{2}{*}{ Behavioral needs } & Sign language $(\mathrm{N}=165)$ & 2.99 & 0.566 & 1.983 & 0.049 \\
\hline & $\begin{array}{l}\text { Total communication } \\
(\mathrm{N}=65)\end{array}$ & 3.14 & 0.498 & & \\
\hline \multirow[t]{2}{*}{ Academic needs } & Sign language $(\mathrm{N}=165)$ & 2.94 & 0.617 & 0.172 & 0.864 \\
\hline & $\begin{array}{l}\text { Total communication } \\
(\mathrm{N}=65)\end{array}$ & 2.92 & 0.665 & & \\
\hline \multirow[t]{2}{*}{ Learning style needs } & Sign language $(\mathrm{N}=165)$ & 2.90 & 0.564 & 4.604 & 0.000 \\
\hline & $\begin{array}{l}\text { Total communication } \\
(\mathrm{N}=65)\end{array}$ & 3.25 & 0.459 & & \\
\hline
\end{tabular}

The data in the table indicates that hearing-impaired students are affected by the dependent variables according to the means. Also, the findings indicate that the differences between pairs of means of students who used sign language and total communication are in favour of students who used total communication for the dependent variables: communication needs, audiological rehabilitation needs, behavioural needs, and learning style needs.

\section{Discussion}

The results of the main question about the special needs of students who are deaf and hard-of-hearing in Jordan indicated that this group of students exhibit needs on all dimensions of the scale. Understanding the situation of hearing-impaired students in Jordan may help to interpret the results. Nowadays, hearing-impaired students are receiving their education at schools not fitted with facilities needed. They study the same curricula and they have the same educational cycles as hearing students. They are taught by teachers that most of them are prepared for educating normal students not hearing-impaired students. The results of the study clearly indicated that hearing-impaired students need special services to be offered to them by well-trained teachers and schools fitted 
with the equipment needed in order to meet their unique needs. For example, they need special curricula that meet their developmental tasks. These results agreed with the findings of the studies by Johnson and Seaton (2012), Dimiling (2010), Wolters, Knoors, Cillessen, Verhoeven (2011), and El-Zraigat and Smadi (2012).

Moores (2001) indicates that there are differences between hearing-impaired students and hearing students in how they are taught, in what they are taught, and in where they should taught. As I have mentioned before, hearing-impaired students need special educational services to be offered to them, such as, speech and language therapy, audiological rehabilitation, professional educational interpreters, modified curricula, adjusted special instructional materials, and special teaching methods. Facilities needed by hearing-impaired students that are delivered by schools for children with hearing impairment in Jordan are not enough because of limited financial support of these schools in Jordan. Therefore, hearing-impaired students need special services, for example, speech and language therapy, audiological rehabilitation, professional educational interpreters and so forth. We should take into consideration that the lack of services offered will negatively impact the development of hearing-impaired students. Consequently, this will lead to cognitive, speech and language, social and emotional, academic difficulties.

In relation to the second question: Do the special needs of students who are deaf and hard-of-hearing in Jordan significantly differ compared to their gender? The result indicates that the differences between all pairs of means for both male and female respondents are statistically non-significant, that is, both male and female have the same needs and they need special services. This result disagreed with the finding of the study by Wolters et al. (2011) which indicated that deaf students who have some problems with their social behaviour affected negatively their social acceptance. They also find that deaf girls showed lower level of antisocial behaviour than deaf boys.

In respect with the third question: Do the special needs of students who are deaf and hard-of-hearing in Jordan significantly differ compared to their level of hearing loss? The results show that the hearing-impaired students who have 55-69 dB hearing loss are more affected by communication needs, audiological rehabilitation needs, and learning style needs than hearing-impaired students who have $90 \mathrm{~dB}$ hearing loss and beyond. The level of 55-69 dB hearing loss may benefit more from assistive technology devices than the level $90 \mathrm{~dB}$ hearing loss and beyond. Therefore, they need hearing assistance, speech and language therapy, and a need for learning style. These findings consistent with Northern and Downs (2002) and Moores (2001).

Regarding the fourth question: Do the special needs of students who are deaf and hard-of-hearing in Jordan significantly differ compared to their grade? The result indicates that the special needs of hearing impaired students differ according to their age; however, the grade groups of 2-5 and 6-8 exhibit communication needs, social and emotional needs, personal needs, behavioural needs, and academic needs than grade group 9-11. These findings maintain that hearing impaired students need social interaction, understanding of others in their surrounding environments, and optimal achievement at schools. Thus, they need special services to be offered to them in order to achieve their maximum potential and adjustment. Beveridge (1997), Bunch (1987), Schrimer (2001) maintain these findings.

In respect to the final question: Do the special needs of students who are deaf and hard-of-hearing in Jordan significantly differ compared to their communication methods? The findings indicate that students who used total communication exhibit strong needs on communication, audiological rehabilitation, behavioural, and learning style needs than students who use sign language. Therefore, students who use total communication need more hearing services and academic counselling or services in order to meet their unique needs.

\section{Recommendations}

Based on the findings and the discussion of this study, the investigator recommends the following strategies in order to meet the special needs of hearing-impaired students: helping the hearing-impaired students to overcome the difficulties resulting from their hearing loss; modifying and developing special curricula that meets their unique needs; supplying the schools for children with hearing impairment with services needed by hearing-impaired students, such as, speech and language therapy, audiological rehabilitation, and professional educational interpreters; and providing this group of students with counselling services in order to help them obtaining social and psychological adjustment.

\section{References}

Anderson-Inman, L., \& Terrazas-Arellannes, F. (2009). Supported eText in captioned videos: A comparison of expanded versus standard captions on student comprehension of educational content. Journal of special education technology, 24(3), 21-34.

Beveridge, S. (1997). Special educational needs in schools. London: Routledge. 
Bunch, G. (1987). The curricula and the students who are deaf and hard-of-hearing: Theoretical and practical considerations. Boston: A College-Hill Publication.

Dahl, M. (1994). Hard of hearing inmates in penitentiaries. Journal of Speech-language pathologist and audiologist, 18(4), 271-278.

Dimiling, L. (2010). Conceptually based vocabulary intervention: Second grade' development of vocabulary words. American annals of the deaf, 55(4), 425-448.

Donne, V., \& Zigmond, N. (2008). An observational study of reading instruction for students who are deaf or hard-of-hearing in public schools. Communication disorders quarterly, 29(4), 219-235. http://dx.doi.org/10.1177/1525740108321448

El-Zraigat, I., \& Smadi, Y. (2012). Challenges of educating students who are deaf and hard-of-hearing in Jordan. International Journal of Humanities and Social Science, 2(8), 150-158.

English, K. (1995). Educational audiology across the lifespan: Serving all learners with hearing impairment. Baltimore: Paul H. Brookes Publishing Co.

Esera, T. (2008). An insight into the educational needs of deaf high school students: Interviews with school staff and students. Kairaranga, 9(2), 32-36.

Gilbertson, D., \& Ferre, S. (2008). Considerations in the identification, assessment, and intervention process for deaf and hard-of-hearing students with reading difficulties. Psychology in schools, 45(2), 104-120. http://dx.doi.org/10.1002/pits.20286

Gillam, R., \& Gillam, S. (2011). An introduction to the discipline of communication sciences and disorders. In Ronald B. Gillam, Thomas P. Marquard, \& Frederick N. Martin (Eds.), Communication sciences and disorders: From science to clinical practice. Boston: Jones and Bartlett Publishers.

Hallahan, D., Kauffman, J., \& Pullen, C. (2012). Exceptional learners: Introduction to special education. Boston: Allyn \& Bacon.

Heward, W. (2006). Exceptional children: An introduction to special education. Upper Sanddle River: Memill\& Prentice Hall.

Houston, K., \& Perigoe, C. (2010). Speech-language pathologist: Vital listening and spoken language professionals. Volta review, 110(2), 219-230.

Johnson, C., \& Seaton, J. (2012). Educational audiology handbook. Australia, United State: Delmar, Cengage Learning.

Moores, D. (2001). Educating the deaf: Psychology, principles, and practice. Boston: Houghton Mifflin Company.

Northern, J., \& Downs, M. (2002). Hearing in children. Philadelphia: Lippincott Williams \& Wilkins.

Paul, P., \& Whitelaw, G. (2011). Hearing and deafness: An introduction to health and education professionals. Boston: Jones and Bartlett Publishers.

Paul, P. (2009). Language and deafness. Boston: Jones and Bartlett Publishers.

Reich, L., \& Lavay, B. (2009). Physical education and sport adaptations for students who are hard-of-hearing. Journal of physical education, recreation \& dance, 80(3), 38-42.

Scheetz, N. (2004). Psychosocial aspects of deafness. Boston: Allyn \& Bacon.

Schick, B., Williams, K., \& Kupermintz H. (2006). Look who's being behind: Educational interpreters and access to education for deaf and hard-of-hearing students. Journal deaf studies and deaf education, 11(1), 3-20. 3-20. http://dx.doi.org/10.1093/deafed/enj007

Schrimer, B. (2001). Psychological, social, and educational dimensions of deafness. Boston: Allyn \& Bacon.

Sinnott, C. (2009). Hands working together for behaviour and academic success. Odyssey: New directions in deaf education, 10(1), 23-26.

Smith, D. (2007). Introduction to special education: Teaching in An age of challenge. Boston: Allyn \& Bacon.

Stach, B. (2010). Clinical audiolgy: An introduction. Clifton Park, NY: Delmar Cengage Learning.

The Ministry of Education. (2010). The Directorate of Special Education. Amman, Jordan. 
Whyte, A., \& Guiffrida, D. (2008). Counselling deaf college students: a case of Shea. Journal of college counselling, 11(2), 184.

Wolters, N., Knoors, H., Cillessen, A., \& Verhoeven, L. (2011). Predicting acceptance and popularity in early adolescence as a function of hearing status, gender, and educational setting. Research in developmental disabilities: A multidisciplinary journal, 32(6), 2553-2565.

\section{Appendix A}

\section{Special Needs of Students who are Deaf and Hard-of-Hearing Scale (SNSDHHS)}

Dear students,

This study aims at assessing your special needs. In the following list there are special needs that may you exhibit. Please, read and answer these needs by putting (x) mark in the suitable square. If you please, do not hesitate to ask any question.

This scale assesses your need to:

\begin{tabular}{|c|c|c|c|c|}
\hline Dimensions & $\begin{array}{l}\text { Strongly } \\
\text { agree }\end{array}$ & agree & disagree & $\begin{array}{l}\text { Strongly } \\
\text { disagree }\end{array}$ \\
\hline \multicolumn{5}{|l|}{ Dimension one: Communication needs } \\
\hline \multicolumn{5}{|l|}{ Speak and use the sounds of speech. } \\
\hline \multicolumn{5}{|l|}{ Understand the meaning of words or language symbols. } \\
\hline \multicolumn{5}{|l|}{$\begin{array}{l}\text { Organise thoughts in the production of language and } \\
\text { speech. }\end{array}$} \\
\hline \multicolumn{5}{|l|}{ Appropriately respond to spoken language. } \\
\hline \multicolumn{5}{|l|}{ Understand and respond into facial expression and gesture. } \\
\hline \multicolumn{5}{|l|}{ Learning takes turn skills in human conversation. } \\
\hline \multicolumn{5}{|l|}{ Use vocabularies in sentences. } \\
\hline \multicolumn{5}{|l|}{ Understand written language. } \\
\hline \multicolumn{5}{|l|}{ Make sentences in speech conversation. } \\
\hline \multicolumn{5}{|l|}{ Learn express skills of personal needs. } \\
\hline \multicolumn{5}{|l|}{ Learn take attention of others in speech conversation. } \\
\hline \multicolumn{5}{|l|}{ Learn repair conversation skills with hearing people. } \\
\hline \multicolumn{5}{|l|}{ Learn skills of keep speech conversation relevant. } \\
\hline \multicolumn{5}{|l|}{ Dimension two: Audiological rehabilitation needs } \\
\hline \multicolumn{5}{|l|}{ Discriminate between speech sounds. } \\
\hline \multicolumn{5}{|l|}{ Learn skills of using hearing aids. } \\
\hline \multicolumn{5}{|l|}{ Learn of maintenance skills of hearing aids. } \\
\hline \multicolumn{5}{|l|}{ Learn listening skills to others. } \\
\hline \multicolumn{5}{|l|}{ Use residual hearing in recognising words. } \\
\hline \multicolumn{5}{|l|}{ Match speech sounds with its printed letters. } \\
\hline \multicolumn{5}{|l|}{ Recognize and understand the rhythm of spoken words. } \\
\hline \multicolumn{5}{|l|}{ Dimension three: Social and emotional needs } \\
\hline \multicolumn{5}{|l|}{ Interact with other persons. } \\
\hline \multicolumn{5}{|l|}{ Make social relationship and friends. } \\
\hline \multicolumn{5}{|l|}{ Apply social conversations to the local environment. } \\
\hline Use non-verbal social cues with others. & & & & \\
\hline
\end{tabular}




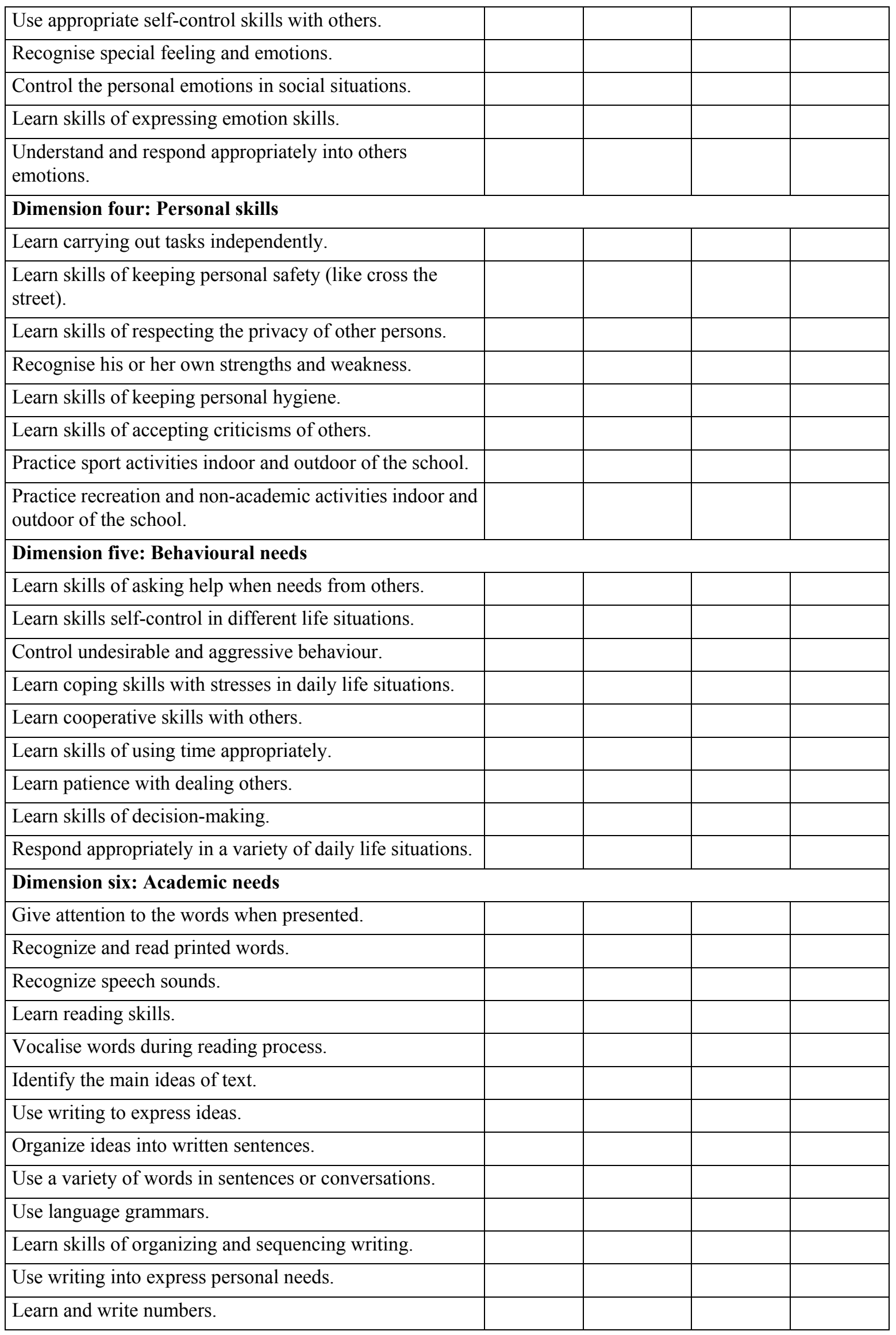




\begin{tabular}{|l|l|l|l|l|}
\hline $\begin{array}{l}\text { Learn and use computations skills (addition, subtraction, } \\
\text { multiplication, and division). }\end{array}$ & & & \\
\hline Learn skills of solving mathematical problems. & & & & \\
\hline Use mathematical language in daily life situations. & & & & \\
\hline Dimension seven: Learning style & & & & \\
\hline Learn by sign language. & & & & \\
\hline Learn by total communication. & & & & \\
\hline Learn by auditory methods. & & & & \\
\hline Learn by using visual aids. & & & & \\
\hline Learn in a variety of milieus. & & & & \\
\hline Learn by using peer tutoring. & & & & \\
\hline Learn by following spoken instructions. & & & & \\
\hline Learn by using modeling. & & & & \\
\hline
\end{tabular}

